Bull. Chem. Soc. Ethiop. 2021, 35(2), 365-380.

(C) 2021 Chemical Society of Ethiopia and The Authors

ISSN 1011-3924

DOI: https://dx.doi.org/10.4314/bcse.v35i2.11

Printed in Ethiopia

Online ISSN 1726-801X

\title{
SYNTHESIS, CHARACTERIZATION, POM ANALYSES AND BIOLOGICAL EVALUATION OF $N$-[(2-METHOXY-5-NITROPHENYL)]-4-OXO-4-[OXY] BUTENAMIDE BASED ZINC(II) CARBOXYLATE COMPLEXES
}

\author{
Muhammad Salam Khan ${ }^{1}$, Muhammad Sirajuddin ${ }^{1 *}$, Muhammad Zubair ${ }^{2}$, Hizbullah Khan ${ }^{1}$, \\ Muhammad Tariq ${ }^{3}$, Shaila Mehwish ${ }^{4}$ and Nazif Ullah ${ }^{4}$ \\ ${ }^{1}$ Department of Chemistry, University of Science and Technology Bannu, 28100, Pakistan \\ ${ }^{2}$ Department of Chemistry, Quaid-i-Azam University, 45320, Islamabad, Pakistan \\ ${ }^{3}$ Institute of Chemical Sciences, Bahauddin Zakariya University, 60000, Multan, Pakistan \\ ${ }^{4}$ Department of Biotechnology, Faculty of Chemical and Life Sciences, Abdul Wali \\ Khan University Mardan, Pakistan
}

(Received January 31, 2019; Revised April 22, 2020; Accepted April 22, 2021)

\begin{abstract}
The aim of medicinal chemistry is to links many scientific disciplines and allows the scientists in researching and developing new drugs with enhance and targeted properties. In this article we are exploring the preparation of four new zinc(II) carboxylate complexes based on $N$-[(2-methoxy-5-nitrophenyl)]-4-oxo-4[oxy]butenamide which were characterized through FT-IR and EDX studies. The DNA binding ability and binding type of complexes were assessed by spectroscopic (UV-Visible) and viscosity measurements, exhibiting an intercalative pattern of interaction. The synthesized compounds were also assessed to know theoretically about their nature by molecular docking studies resulting also in intercalation mode. Analysis of the complexes for biological applications such as anti-microbial, anti-leishmanial, cytotoxicity and DNA damage activities showed that these complexes carries good anti-microbial, anti-leishmanial activity with no toxicity to human blood thyrocytes and DNA. The bioavailability prediction and drug likeness score has also been evaluated through Insilco studies.
\end{abstract}

KEY WORDS: Zn(II) carboxylate complex, DNA binding, Anti-leishmanial activity, Cytotoxicity, Docking study

\section{INTRODUCTION}

Zinc has got importance because of its catalytic, enhanced biological activities of ligand along with highly inhibiting activities against fungal and bacterial growth [1-3]. The amide-based carboxylate ligands were designed for the current study because of the existence of peptide bonds in its structures which is highly important on the biological side because of its larger hydrophilic character as compared to the simple carboxylates $[4,5]$. The carboxylate complexes of zinc(II) with ligands of nitrogen or oxygen donors have been proved highly significant in biochemical aspects, i.e. biological and chemical point of view in current era $[6,7]$.

In coordination chemistry, $\mathrm{Zn}$ is an attractive central metal ion and is an essential part of all enzyme classes. Zinc performs diverse physiological functions in many biological processes, for example, as a structural component, as a catalytic factor, or as a signaling mediator [8]. Curcuminate based zinc(II) complexes having an aromatic spectator ligands displayed in vitro anticancer activity against various cancer cell lines [9]. Some $\mathrm{Zn}$ (II) carboxylate complexes have shown excellent anti-diabetic activity as $\mathrm{Zn}$ plays a vital role in insulin storage and secretion, as well as its reported insulin mimetic properties [10]. Zn(II) complexes have also displayed antitumor activity against human cancer cell lines because of the cytoprotective nature of $\mathrm{Zn}$ and suppresses apoptotic pathways [11]. Amide based $\mathrm{Zn}$ (II) carboxylate complexes have also been used for Alzheimer's disease treatment against acetylcholinesterase (AChE) and butyrylcholinesterase (BChE) [12].

${ }^{*}$ Corresponding author. E-mail: m.siraj09@gmail.com

This work is licensed under the Creative Commons Attribution 4.0 International License 
New drugs with better cure rates and minimum side effects are required for the cancer treatment. Coordination chemistry presents lot of compounds having various geometries, different redox reactivity and different modes of attachment to DNA, e.g. cis-platin and other platinum coordination compounds are among the most widely used drugs for cancer treatment. Due to some sever side effect of Pt based drugs, coordination compounds of other than Pt metals with good antitumor activity got the attention of the researcher for the development of new anticancer agents [13]. Zinc(II) carboxylates possess various mode of interaction with DNA like intercalation, grove binding and electrostatic interaction [14-16].

The aim of this research work is to prepare $N$-[(2-methoxy-5-nitrophenyl)]-4-oxo-4[oxy]butenamide based complexes of $\mathrm{Zn}$ with oxygen/nitrogen donor ligands capable of exploiting the antimicrobial, anti-leishmanial activities and carries lesser toxicity to human blood erythrocytes and DNA.

\section{EXPERIMENTAL}

\section{Materials and methods}

Solvents and other required chemicals of analytical grade purity were obtained from Sigma and Alfa Aesar and used as such as received. A digital Electro-thermal melting point instrument was used to determine the melting points of the prepared samples. FTIR spectra in the range of $4000-400 \mathrm{~cm}^{-1}$ of prepared compounds were obtained using Thermo fisher FTIR spectrophotometer. The DNA binding interaction was validated through UV-Visible spectrophotometer. EDX instrument was employed to determine the elemental compositions of the prepared compounds.

\section{Synthesis of N-[(2-methoxy-5-nitrophenyl)]-4-oxo-4-[oxy]butenamide (HL) and NaL}

The ligand HL was re-synthesized by dissolving in glacial acetic acid separately maleic anhydride and 2-methoxy-5-nitroaniline and then mixed them slowly. The mixture was stirred at $25^{\circ} \mathrm{C}$ and precipitate formed after few min. The resulting precipitate was filtered and washed thoroughly using $\mathrm{H}_{2} \mathrm{O}$ to get the desired product after air dry [17].

Sodium salt $(\mathrm{NaL})$ was obtained by following the procedure described by Sirajuddin and coworker [17] by the slow addition of $\mathrm{NaHCO}_{3 \text { (aq) }}$ to a flask containing suspended solution of ligand, $\mathrm{HL}$ in distilled $\mathrm{H}_{2} \mathrm{O}$. After few min stirring at $25^{\circ} \mathrm{C}$, a clear solution was achieved which gives the required $\mathrm{NaL}$ product after rotary evaporation of $\mathrm{H}_{2} \mathrm{O}$ (Scheme 1).

Synthesis of bis(N-(2-methoxy-5-nitrophenylamino)-4-oxo-4-[oxy]butenamide)zinc(II) (1)

Complex 1 was obtained by reacting an aqueous solutions of $\mathrm{NaL}(4 \mathrm{mmol}, 1.16 \mathrm{~g})$ and zinc sulfate ( $2 \mathrm{mmol}, 0.574 \mathrm{~g})$ in 2:1 stoichiometric ratio at room temperature [18] as presented in Scheme 1. Precipitate of the required complex 1 was appeared after stirring the resulting mixture at $25^{\circ} \mathrm{C}$. Precipitates of the required complex 1 was filtered, washed with distilled $\mathrm{H}_{2} \mathrm{O}$ and dried. The desired complex was tried for crystallization in different solvents like methanol and DMSO but failed to get good quality crystals.

Synthesis of 2,2'-bipyridine bis(N-(2-methoxy-5-nitrophenylamino)-4-oxo-4-
[oxy]butenamide)zinc(II) (2)

The same procedure as described for complex 1 was practiced for getting the complex $\mathbf{2}$ with additional step in which a $0.23 \mathrm{~g}(1.5 \mathrm{mmol})$ of 2,2'-bipyridine in $2-3 \mathrm{~mL} \mathrm{MeOH}$ was slowly added to the mixture to get the desired product [18]. 
Synthesis and characterization of $N$-[(2-methoxy-5-nitrophenyl)]-4-oxo-4-[oxy]butenamide 367

Synthesis of pyridine bis(N-(2-methoxy-5-nitrophenylamino)-4-oxo-4-[oxy]butenamide)zinc(II) (3)

The same procedure as described for complex 1 was practiced for getting the complex $\mathbf{3}$ with additional step in which a $0.12 \mathrm{~mL}(1.5 \mathrm{mmol})$ of pyridine in $2-3 \mathrm{~mL} \mathrm{MeOH}$ was slowly added to the mixture to get the desired product [18]. Synthesis of 1,10-phenanthroline bis(N-(2-methoxy-5-nitrophenylamino)-4-oxo-4-
[oxy]butenamide)zinc(II) (4)

The same procedure as described for complex 1 was practiced for getting the complex 4 with additional step in which a $0.29 \mathrm{~g}(1.5 \mathrm{mmol})$ of 1,10 -phen. in 2-3 $\mathrm{mL} \mathrm{MeOH}$ was slowly added to the mixture to get the desired product [18].

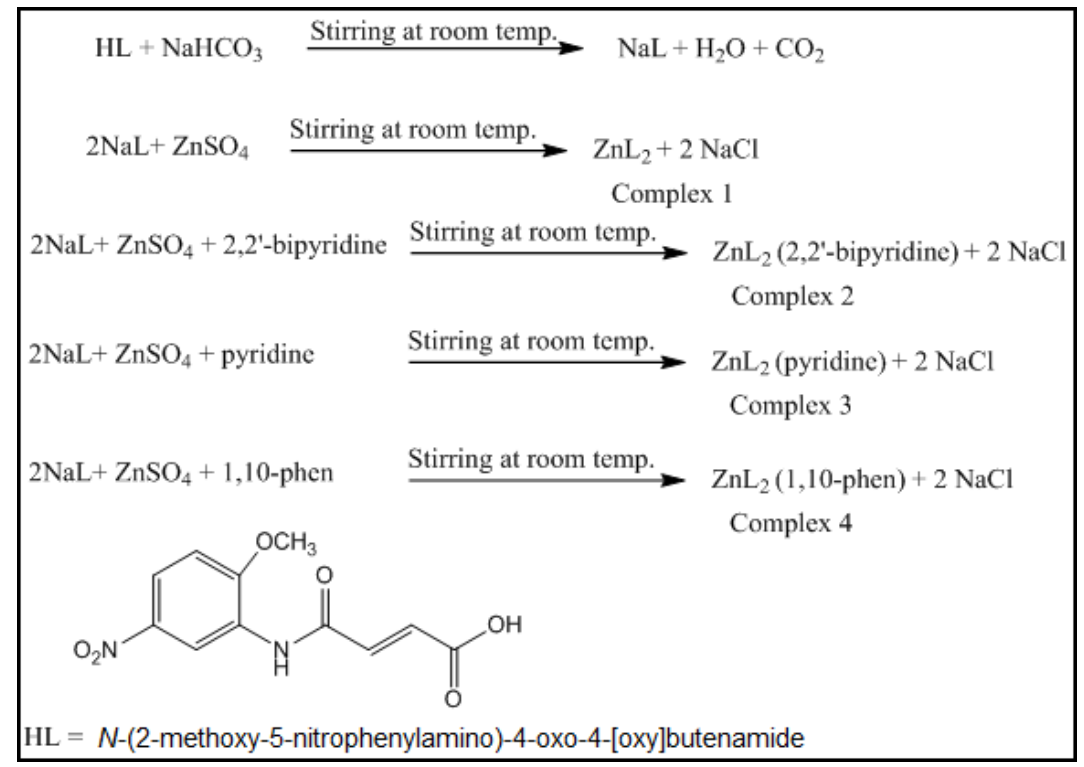

Scheme 1. Synthetic way for the preparation of complexes 1-4.

Complex-DNA binding study via UV-Visible spectroscopy

The deoxyribonucleic acid solution was obtained by the dissolution of small amount of sodium salt of SS-DNA in distilled water that was kept on stirring at room temperature for overnight to get the clear homogeneous solution. The ratio of $n / p$ (nucleotide to protein) ratio for the prepared solution was obtained from the absorbance ratio of $\mathrm{A}_{260} / \mathrm{A}_{280}$ and was about of 1.9 which indicates that DNA is free from protein. The concentration of DNA was calculated to be $1.97 \times 10^{-4} \mathrm{M}$ via using the molar absorptivity value $6600 \mathrm{M}^{-1} \mathrm{~cm}^{-1}$ at $260 \mathrm{~nm}$ [19-21]. The DNA solution was stored at $4{ }^{\circ} \mathrm{C}$. Complex solutions $(20 \mu \mathrm{M})$ were prepared and screened for DNAbinding studies. The concentrations of complexes were kept constant while that of the SS-DNA was varied during the experiment. To both the complex and reference cell, an same quantities of DNA concentration were added to get variable absorbance [22, 23]. 
Complex-DNA binding study via viscometry

The viscosity of complex-DNA adduct was measured using the Ubbelohde Viscometer at room temperature to know the binding behavior of the complex-DNA interaction. In order to record mean flow time the process was done in triplicate. The data were plotted between the relative viscosity and the ratio of the complex-DNA concentration, i.e. $\left(\eta / \eta_{\mathrm{o}}\right)^{1 / 3} v s$. ([Complex $\left.] /[\mathrm{DNA}]\right)$. Here $\eta$ is the viscosity in the presence of the complex and $\eta_{0}$ signifies the viscosity of the DNA in the absence of the complex [24].

Anti-bacterial activity assay

The anti-bacterial activity of the screened compounds against five bacterial strains (Klebsila pneumonia, Streptococcus auras and Escherichia coli were determined using well diffusion assay. All the experimental materials and nutrient agar media were sterilized while autoclaved for twenty min at $121{ }^{\circ} \mathrm{C}$. Zinc(II) carboxylates complexes of $1 \mathrm{mg} / \mathrm{mL}$ to $6 \mathrm{mg} / \mathrm{mL}$ were prepared in DMSO. Azithromycin and DMSO were used +ve and -ve controls, respectively. A saline solution of $0.49 \mathrm{~g} \mathrm{NaCl}$ in $50 \mathrm{~mL}$ distilled water was also prepared. A homogeneous solution of Stock nutrient Agar was obtained by dissolving $5.5 \mathrm{~g}$ of it taken using digital balance and was solubilized in $200 \mathrm{~mL}$ distilled $\mathrm{H}_{2} \mathrm{O}$ [25-30].

Anti-fungal activity assay

Different dilutions of the screened samples were prepared having concentrations $1-6 \mathrm{mg} / \mathrm{mL}$ in DMSO. Respective solution of Turbinofine was also prepared in DMSO which was used as +ve control. Sabouraud dextrose agar media was prepared by dissolution of $4.5 \mathrm{~g}$ of SDA in $80 \mathrm{~mL}$ distilled water. After that all experimental materials and media (SDA) were sterilized while autoclaved for twenty min at $121{ }^{\circ} \mathrm{C}$. The experimental activities were carried out in laminar flow which provide microbes free environment. The SDA was poured in test tubes and kept in slant position. After SDA solidification $60 \mu \mathrm{L}$ concentration from stock solutions of each complex were added in each corresponding labeled test tubes. The media along with samples were kept for some time to get solidified. After solidification fungal strains Aspergillus niger and Aspergillus flavus were applied on each test tube with the help of wire loop. All the test tubes were closed through cotton swabs and kept in incubator at $37^{\circ} \mathrm{C}$. The inhibition was measured once after $24 \mathrm{~h}$ and again after $72 \mathrm{~h}$ [31-33].

Anti-promastigote assay

The anti-promastigoate activity of the prepared compounds was performed by following the procedure described by Mehwish and co-worker [34] using MTT assay [35]. The activity of the compounds at four different concentrations (prepared in serial dilution in the range of 500-62.5 $\mu \mathrm{g} / \mathrm{mL}$ ) were accessed.

\section{Cytotoxicity assay}

The prepared compounds were tested to explore their cytotoxicity activity performed by following the procedure described earlier [34, 36]. Fresh human blood was collected from volunteers and $\mathrm{RBC}$ were obtained by centrifugation after washing three times with PBS. A 990 $\mu \mathrm{L}$ of the remaining RBC (red blood cells) were treated with each sample (complexes 1-4) such that the final tested concentration reaches at $500,250,125 \mu \mathrm{g} / \mathrm{mL}$ followed by incubation at 37 ${ }^{\circ} \mathrm{C}$ for $3 \mathrm{~h}$ and then the cells were centrifuged for five min at with $1000 \mathrm{rpm}$. The supernatants were collected and the released hemoglobin was confirmed at $576 \mathrm{~nm}$ using spectrophotometer. 
Dimethyl sulfoxide and Triton X-100 (0.5\%) were employed as -ve and +ve controls, respectively. With the help of Elisa plate reader, the OD was obtained at $576 \mathrm{~nm}$ and \% hemolysis was determined by the formulashown in equation 1 [37].

Hemolysis (\%) $=\frac{\text { OD } 576 \mathrm{~nm} \text { in sample solution - OD } 576 \mathrm{~nm} \text { in PBS }}{\text { OD } 576 \mathrm{~nm} \text { in } 0.5 \% \text { Triton - OD } 576 \mathrm{~nm} \text { in PBS }} \times 100$

DNA damage analysis (DNA laddering assay)

The DNA damage was studied by DNA laddering assay as described earlier [38]. The DNA material was extracted from fresh human blood (obtained earlier for cytotoxicity assay) using phenol/chloroform (1:1) method. A $0.5 \mathrm{mg} / \mathrm{mL}$ proteinase $\mathrm{K}$ was added to harvest and resuspend the cells in digestion buffer. In the presence of RNase A, the mixture was incubated at $37^{\circ} \mathrm{C}$ for $3 \mathrm{~h}$ and precipitated by adding sodium acetate and ice-cold ethanol to the aqueous phase followed by overnight incubation at $-20^{\circ} \mathrm{C}$ and was treated with different concentrations $(500 \mu \mathrm{g} / \mathrm{mL})$ of selected compounds (complexes) for $3 \mathrm{~h}$. The mixture was centrifuged, and pellets were collected, allowed to dry and re-suspended in tris-EDTA buffer. Using a trisacetate-EDTA running buffer on $2 \%$ agarose gel, $20 \mu \mathrm{g}$ DNA aliquots were then electrophoresed and photographed under ultraviolet light. [39-41].

\section{Theoretical study by molecular docking}

Molecular docking study was performed to get the information about the interaction between the drug target and compound [42]. For this MOE-Dock program (www.chemcomp.com) was used. MOE (molecular operating environment) software was employed to draw the 3D structure of the metal-complex analogs [43]. A 3D protonated structure of all compounds was drawn which were then minimized by using the default parameters of the MOE. From the protein databank (PDB), the 3D crystal structure of the DNA (1 bna) was obtained and the tested compounds were docked into the active site of the target receptor in MOE by the default parameters as described in earlier [4] and by using MOE software the best poses were obtained after docking.

\section{RESULTS AND DISCUSSION}

The physical data including the molecular formula, mass, physical state, solubility, color and melting points of the prepared $\mathrm{Zn}(\mathrm{II})$ carboxylate complexes is given in Table 1 . The complexes were freely soluble in DMSO and some also in methanol. The sharp melting points of the synthesized compounds show their purity.

\section{Characterization of synthesized compounds by FTIR}

Table 1 presents the selected FTIR peaks observed in the synthesized compounds spectra. The deprotanation of the ligand HL was confirmed by the absence of $\mathrm{OH}$ peak at $3250 \mathrm{~cm}^{-1}$. The symmetric vibration peaks in complexes are present in the range of $1337-1344 \mathrm{~cm}^{-1}$ while the asymmetric vibration peaks appears in the range of $1522-1530 \mathrm{~cm}^{-1}$. A decrease in the value of symmetric vibration and increase in the value of asymmetric vibration was observed after complexation compared to that of the free ligand because of the attachment of oxygen of the carboxylate moiety with $\mathrm{Zn}$ atom [44]. The difference between asymmetric and symmetric vibrations $(\Delta v)$ for complexes 1-4 are 183,192, 188 and $182 \mathrm{~cm}^{-1}$, receptively, indicating bidentate mode of coordination of carboxylate moiety to $\mathrm{Zn}$ atom as $\Delta v$ for complexes $<<\Delta v$ for $\mathrm{NaL}[5]$. The complex formation was also confirmed by the appearance of $\mathrm{Zn}-\mathrm{O}$ absorption bands at 428, 430, 424 and $420 \mathrm{~cm}^{-1}$, respectively in complexes 1-4 [5, 45]. The attachment of 2,2'-bipyridine, pyridine and 1,10-phenanthroline group in complexes was observed at 516, 470 and $479 \mathrm{~cm}^{-1}$ because of $\mathrm{Zn}-\mathrm{N}$ peak [5]. 
Table 1. Physical and FTIR data $\left(\mathrm{cm}^{-1}\right)$ of HL NaL and corresponding zinc(II) carboxylate complexes 1-4.

\begin{tabular}{|l|c|c|c|c|c|c|}
\hline \multicolumn{7}{|c|}{ Physical data } \\
\hline Comp. No. & Mol. formula & Mol. mass & Nature & Color & Solubility & M. P. $\left({ }^{\circ} \mathrm{C}\right)$ \\
\hline $\mathbf{1}$ & $\mathrm{C}_{20} \mathrm{H}_{18} \mathrm{~N}_{4} \mathrm{O}_{12} \mathrm{Zn}$ & 571.77 & Powder & Light yellow & DMSO & $150-152$ \\
\hline $\mathbf{2}$ & $\mathrm{C}_{30} \mathrm{H}_{26} \mathrm{~N}_{6} \mathrm{O}_{12} \mathrm{Zn}$ & 727.95 & Powder & Dark yellow & $\begin{array}{c}\text { DMSO, } \\
\text { MeOH }\end{array}$ & $118-120$ \\
\hline $\mathbf{3}$ & $\mathrm{C}_{25} \mathrm{H}_{23} \mathrm{~N}_{5} \mathrm{O}_{12} \mathrm{Zn}$ & 650.87 & Powder & Off white & $\begin{array}{c}\text { DMSO, } \\
\text { MeOH }\end{array}$ & $147-149$ \\
\hline $\mathbf{4}$ & $\mathrm{C}_{32} \mathrm{H}_{26} \mathrm{~N}_{6} \mathrm{O}_{12} \mathrm{Zn}$ & 751.97 & Powder & Yellow & DMSO & $98-100$ \\
\hline \multicolumn{7}{|c|}{ FTIR data $\left(\mathrm{cm}^{-1}\right)$} \\
\hline IR Peak & HL & NaL & $\mathbf{1}$ & $\mathbf{2}$ & $\mathbf{3}$ & $\mathbf{4}$ \\
\hline$v(\mathrm{OH})$ & 3120 & Absent & Absent & Absent & Absent & Absent \\
\hline$v(\mathrm{COO})_{\text {asy }}$ & 1540 & 1552 & 1527 & 1530 & 1525 & 1522 \\
\hline$v(\mathrm{COO})_{\text {sym }}$ & 1276 & 1301 & 1344 & 1338 & 1337 & 1340 \\
\hline$\Delta v$ & 264 & 251 & 183 & 192 & 188 & 182 \\
\hline$v(\mathrm{C}=\mathrm{C})$ & 1594 & 1664 & 1633 & 1681 & 1648 & 1645 \\
\hline$v(\mathrm{Zn}-\mathrm{O})$ & Absent & Absent & 428 & 430 & 424 & 420 \\
\hline$v(\mathrm{Zn}-\mathrm{N})$ & Absent & Absent & Absent & 516 & 470 & 479 \\
\hline$v(\mathrm{~N}-\mathrm{H})$ & 3347 & 3364 & 3505 & 3550 & 3499 & 3367 \\
\hline$v(\mathrm{C}=\mathrm{O})$ & 1716 & 1714 & 1700 & 1702 & 1705 & 1704 \\
\hline
\end{tabular}

\section{EDX analysis}

The prepared complexes were also characterized by EDX to study the presence of $\mathrm{Zn}$. Since EDX is used mainly for the detection of heavy metals and is not suitable for the lighter elements like carbon or oxygen atoms. The presence of $\mathrm{Zn}$ metal in the composition confirms the complex formation as shown in Table 2. The variation is the percentage composition is due to the fact that EDX is only good for heavy metal detection.

Table 2. Elemental analysis of complex 1 through EDX.

\begin{tabular}{|l|l|l|l|l|}
\hline Element & Line type (series) & Apparent concentration & Weight $\%$ & Factory standard \\
\hline $\mathrm{C}$ & $\mathrm{K}$ & 40.32 & 53.10 & Yes \\
\hline $\mathrm{N}$ & $\mathrm{K}$ & 0.15 & 0.88 & Yes \\
\hline $\mathrm{O}$ & $\mathrm{K}$ & 43.36 & 37.01 & Yes \\
\hline Zn & $\mathrm{L}$ & 6.82 & 9.03 & Yes \\
\hline Total & & & 100 & \\
\hline
\end{tabular}

DNA binding studies by UV-Visible spectroscopy

While studying absorption spectra for complexes one prominent peak was observed having variable wavelength and absorbance in the absence of DNA. The resultant peak appears as a result of $\pi-\pi^{*}$ transitions along with aromatic chromosphere in complex. After the addition of DNA solution into the complex solution, changes takes place in absorbance and wavelength, which shows the interaction between complex and DNA [46]. A hypochromic with slight red shift recorded in the spectra of the screened complexes upon the addition of DNA solution which is an indication of the intercalation type of interaction between the DNA and the compound. The $\pi^{*}$ orbital of intercalated complex molecule interact with the $\pi$ orbital of the DNA bases resulting in the reduction of $\pi-\pi^{*}$ transition probability giving the bathochromic effect and supports the intercalation binding mode. The DNA binding constant $\mathrm{K}_{\mathrm{b}}\left(\mathrm{M}^{-1}\right)$ was obtained from the intercept to slope ratio of a plot of $\mathrm{A}_{\mathrm{o}} /\left(\mathrm{A}-\mathrm{A}_{\mathrm{o}}\right)$ vs. 1/[DNA] [47]. The DNAcomplex interaction was stable and the binding was spontaneous which was confirmed from the -ve $\Delta \mathrm{G}$ value. The effects for complexes $\mathbf{1 , 2 , 3}$ and $\mathbf{4}$ are shown in Figure 1. 
Synthesis and characterization of $N$-[(2-methoxy-5-nitrophenyl)]-4-oxo-4-[oxy]butenamide 371
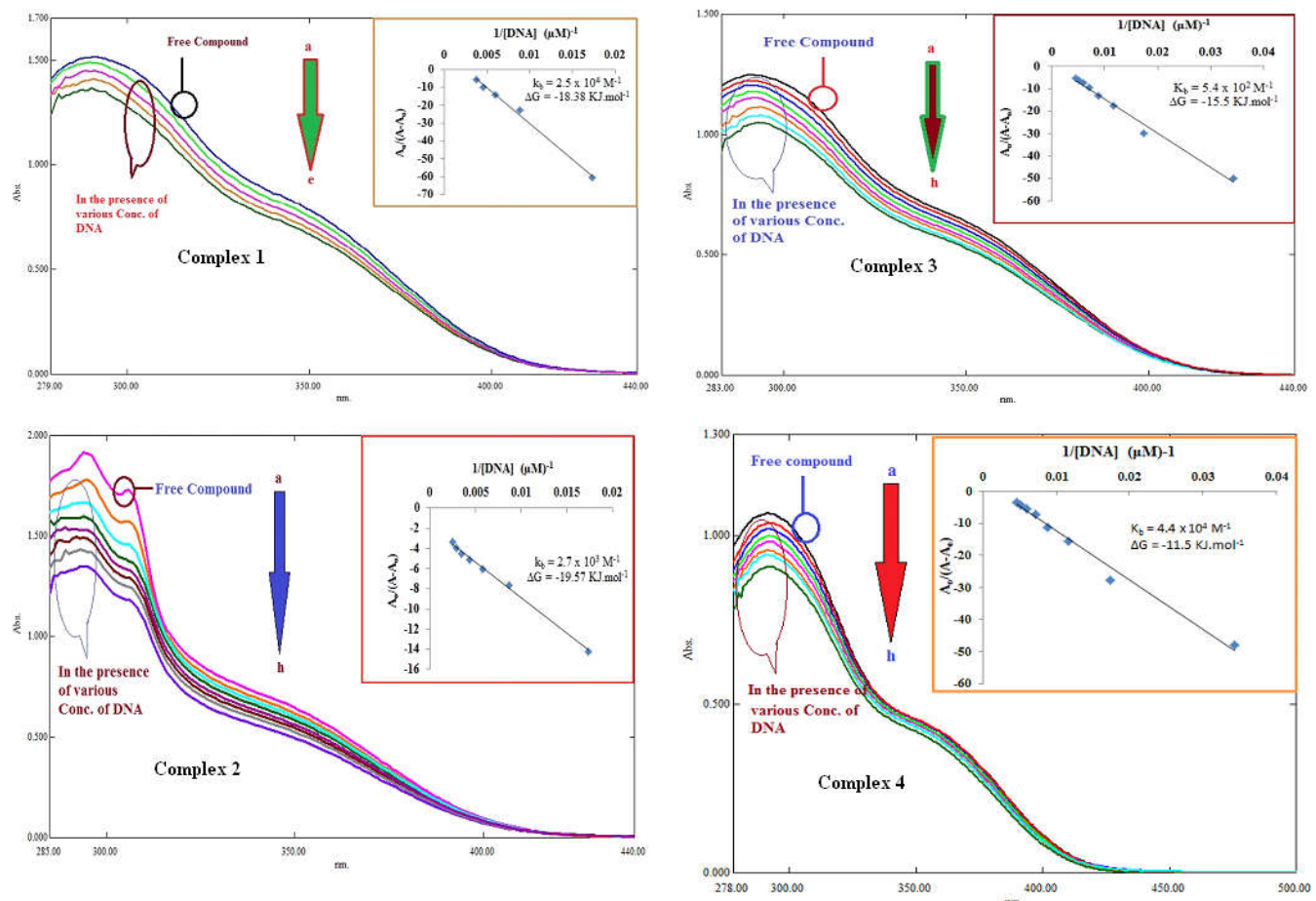

Figure 1. UV-Visible spectrum of $1 \mathrm{mM}$ complexes (1-4)-DNA adduct with and without the presence of various concentrations of DNA: a (free comp.) and b-g (10-70 $\mu \mathrm{M}$ DNA with $10 \mu \mathrm{M}$ DNA increment).

DNA binding studies by viscometry

The complex binding mode to deoxy ribonucleic acid (DNA) was also confirmed using viscometer. The time flow for various concentrations was recorded. The graph for viscosity was plotted as $\left(\eta / \eta_{\mathrm{o}}\right)^{1 / 3}$ vs. $\mathrm{r}=$ [Compound $] /[\mathrm{DNA}]$. The intercalated binding mode of complex to DNA was confirmed from the increase in viscosity. The relative viscosity of the free DNA and in the presence of various concentration of the complexes were determined from time flow using equations 2 and 3 [48]:

$\eta_{\mathrm{o}}=t-\mathrm{t}_{\mathrm{o}}$

$\eta=\frac{t-t_{0}}{t_{0}}$

where $t_{0}$ and $t$ are the time flow in the absence and presence of DNA, respectively.

The representative plot of complex 2 with DNA shows the intercalative mode of interaction in Figure 2A. 


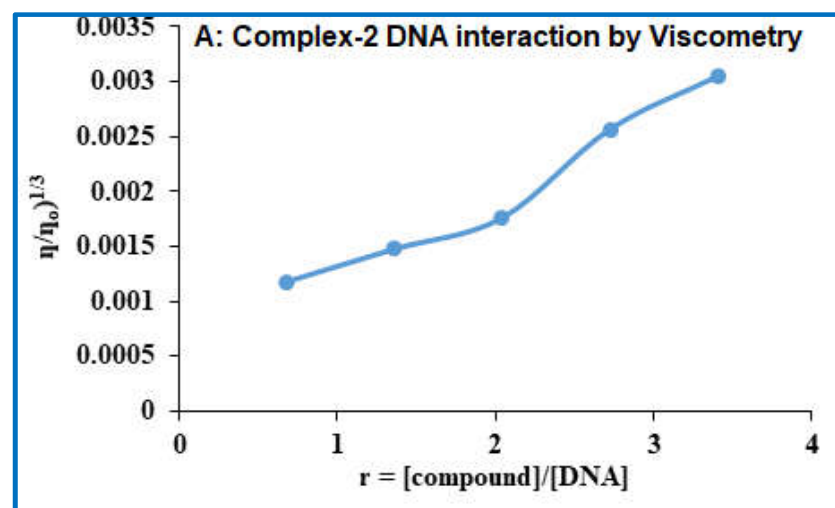

\section{B: Molecular docking structure of complex 4 with DNA}

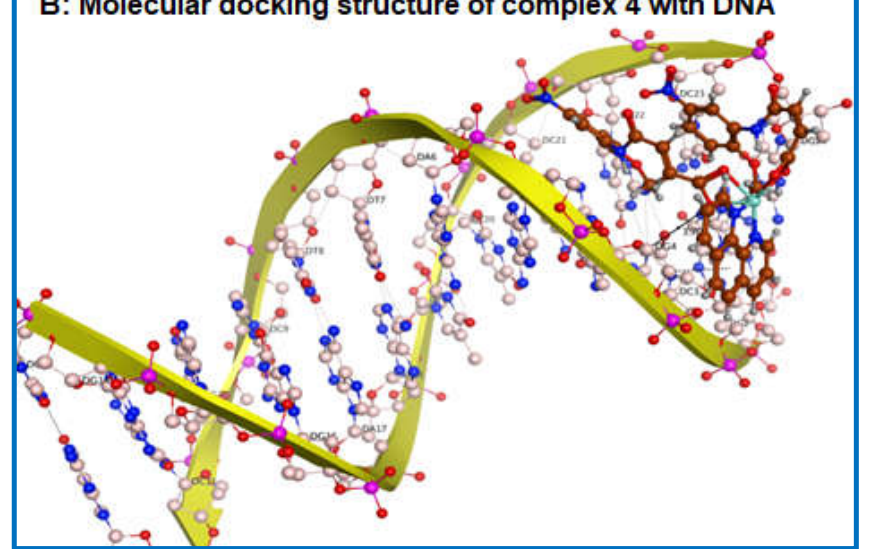

Figure 2. (A) Plot of relative viscosity $v$ s. $r=$ [compound]/[DNA] in which the conc. of complex 2 is varied DNA conc. is constant and (B): molecular docking structure of complex 4 with DNA.

\section{Analysis of anti-microbial activity}

The synthesized complexes were screened for their anti-bacterial potential and their activity was compared with standard antibiotic, Azithromycin. The maximum activity of 23, 22 and $24 \mathrm{~mm}$ were shown by Azithromycin against Klebsila pneumonia, Streptococcus auras and Escherichia coli, respectively. It was observed that the antibacterial activities were increased with increasing complex concentration (Table 3). The minimum activity was shown by $1 \mathrm{mg} / \mathrm{mL}$ while maximum activity was shown by complex having concentration of $6 \mathrm{mg} / \mathrm{mL}$.

The complexes were evaluated after incubation period for their anti-fungal activity using Terbinafine (shows maximum inhibition) and DMSO (shows zero inhibition) as +ve and -ve controls, respectively (Table 3 ). It was summarized that the minimum anti-fungal activities were shown at concentration of $1 \mathrm{mg} / \mathrm{mL}$ while maximum activity shown at $6 \mathrm{mg} / \mathrm{mL}$. The recorded data was compared with standard anti-fungal drug and negative control. It was summarized that with the increase in complex concentration increase the anti-bacterial activity as shown by various concentration results. 
Table 3. Antimicrobial activity results of the screened compounds.

\begin{tabular}{|c|c|c|c|}
\hline \multirow{2}{*}{ Complex No. } & \multicolumn{3}{|c|}{ Zone of Inhibition (mm)for anti-bacterial activity results at $6 \mathrm{mg} / \mathrm{mL}$} \\
\hline & K. Pneumonia & S. Auras & E. Coli \\
\hline 1 & 12 & 14 & 15 \\
\hline 2 & 15 & 15 & 17 \\
\hline 3 & 13 & 18 & 17 \\
\hline 4 & 15 & 16 & 16 \\
\hline Azithromycin & 23 & 22 & 24 \\
\hline \multicolumn{4}{|c|}{ Anti-fungal activity results at $6 \mathrm{mg} / \mathrm{mL}$} \\
\hline \multirow[b]{2}{*}{ Complex No. } & \multicolumn{2}{|c|}{ Zone of Inhibition (mm) } & \% Inhibition \\
\hline & A. niger & A. flavus & $\begin{array}{cc}\text { A. } & \text { niger } / A . \\
& \text { flavus }\end{array}$ \\
\hline 1 & 18 & 24 & $36 / 48$ \\
\hline 2 & 18 & 21 & $36 / 42$ \\
\hline 3 & 19 & 18 & $38 / 36$ \\
\hline 4 & 25 & 30 & $50 / 60$ \\
\hline DMSO & 0 & 0 & 0 \\
\hline Terbinafine & 50 & 50 & 100 \\
\hline
\end{tabular}

Anti-leishmanial activity of zinc(II) carboxylate complexes

Anti-promastigote assay of the tested compounds was performed by MTT assay using Amphotericin B as a standard and their data displayed that against $L$. tropica promastigote these compounds are highly active at all concentrations. Percentage inhibition of promastigote $L$. tropica treated with various concentrations of complex after $72 \mathrm{~h}$ of incubationis given in Table 4. The highest activity was shown by complexes $\mathbf{4}>\mathbf{3}>\mathbf{1}>\boldsymbol{2}$. All the complexes showed over $90 \%$ inhibition at $500 \mu \mathrm{g} / \mathrm{mL}$ tested against promastigote. The highest activity of complex 4 may due be greater lipophilic character due to the presence of 1,10-phenthroline moiety. The data clearly indicate that dose and time dependent activity was observed for the screened compounds.

\section{Cytotoxicity analysis}

The quality of chemical and other substances being lethal to cells is called cytotoxicity for example certain immune cells and venoms [49]. The interaction of molecules with the cells (RBC's) results in the formation of membrane pores which ultimately results in the hemolysis of cell membrane by colloid osmotic mechanism to release hemoglobin. The hemolytic activity of the screened compounds was then determined spectrophotometrically by measuring the released hemoglobin. Previously this assay has been used as a reliable model for screening pharmaceutical agents designed for intracellular delivery of biologic drugs. Keeping in view the importance of the test compounds it is worth testing the possible cytotoxic effect toward human red blood cells. The percent hemolytic activity of the screened compounds explored that the screened compounds were non hemolytic to human blood erythrocytes at all tested concentrations (Table 4). 
Table 4. Percentage inhibition of promastigote L. tropica treated with various concentrations of complexes 1-4 after $72 \mathrm{~h}$ of incubation and percent hemolysis of complexes 1-4 after 3 $\mathrm{h}$ of incubation at various concentrations.

\begin{tabular}{|c|c|c|c|c|}
\hline \multirow{3}{*}{ Complex No. } & \multicolumn{4}{|c|}{ Anti-leishmanial activity } \\
\hline & \multicolumn{4}{|c|}{ Concentration in ppm } \\
\hline & 500 & 250 & 125 & 62.5 \\
\hline 1 & 95.31154 & 89.82110 & 83.09685 & 69.33991 \\
\hline 2 & 92.16533 & 88.21715 & 41.70265 & 38.92659 \\
\hline 3 & 95.1851 & 91.48674 & 90.00617 & 45.71252 \\
\hline 4 & 99.81210 & 99.10140 & 89.71452 & 88.31020 \\
\hline $\begin{array}{c}\text { Amphotericin B } \\
(0.33-0.004 \mu \mathrm{g} / \mathrm{mL})\end{array}$ & \multicolumn{4}{|c|}{100} \\
\hline \multicolumn{5}{|c|}{ Cytotoxicity analysis } \\
\hline \multirow{2}{*}{ Complex No. } & \multicolumn{4}{|c|}{ Concentration in $\mathrm{ppm}$} \\
\hline & 500 & & & 500 \\
\hline 1 & 1.1 & & & 1.0 \\
\hline 2 & 1.0 & & & 0.9 \\
\hline 3 & 1.0 & & & 1.0 \\
\hline 4 & 1.4 & & & 1.3 \\
\hline Triton X $100(0.5 \%)$ & \multicolumn{4}{|c|}{100} \\
\hline PBS & \multicolumn{4}{|c|}{0.004} \\
\hline
\end{tabular}

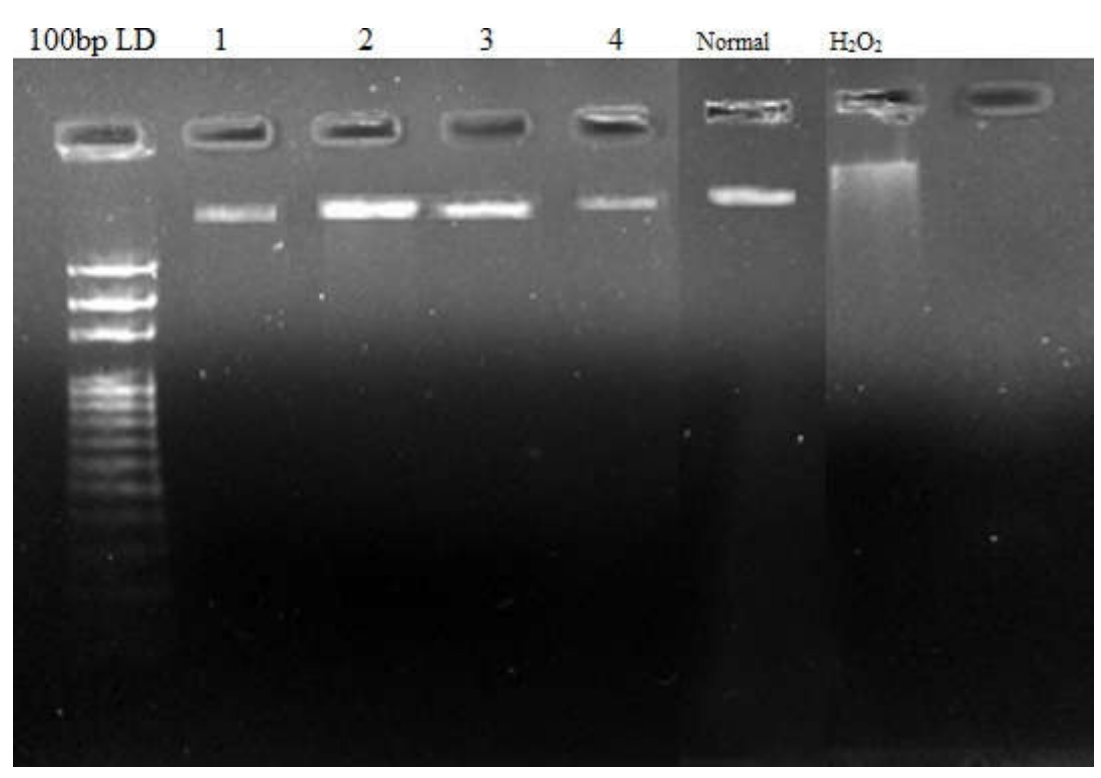

Figure 3. DNA laddering assay showing no prominent DNA degradation effects of different compounds $1,2,3,4$ at $500 \mu \mathrm{g} / \mathrm{mL}$, with control on the rightmost and ladder on the leftmost side.

DNA damage analysis (DNA laddering assay)

DNA damage may be referred to as the ability of chemical agent that damages the genetic material inside the cell causing unexpected changes such as mutations, inappropriate event 
activation and other structural changes which may cause serious illness such as cancer [50]. This assay has the importance that it not only confirms degradation or damage occurring to DNA but it also gives an idea about apoptosis. Our findings suggested that these complexes have no obvious DNA laddering/smears/tailing profile when compared with the ladder and positive control $\mathrm{H}_{2} \mathrm{O}_{2}$ (Figure 3 ). Lower DNA damage activity and nontoxic naturefurther increments the significance of these complexes in the field of drug development.

\section{POM analysis}

POM physico-chemical analysis or ADME/T is important to qualify drugs and their efficacy as leading candidates against various diseases. The POM physicochemical calculations included a partition coefficient (cLogP), aqueous solubility, donor hydrogen bond and drug likeness, which are evaluated in terms of Lipinski's rule-of-five. To qualify oral bioavailability, the topological polar surface (TPSA) should be $<140 \AA^{2}$ [33]. In our compounds the value of TPSA is $<140$ except only for complex 1 . The presence of two different pharmacophore sites: $\mathrm{NH}-\mathrm{C}-\mathrm{C}-\mathrm{N}=\mathrm{O}$ (potential antibacterial pharmacophore site) and $\mathrm{O}=\mathrm{C}-\mathrm{C}-\mathrm{C}-\mathrm{C}=\mathrm{O}$ (potential antifungal/antiviral pharmacophore) make the synthesized complexes quit interesting from biological point of view [47].

From molinspiration data (Table 5) it was concluded that the synthesized complexes obey the rule of Lipinski behave as a drug and to have kinase and enzyme inhibition properties. As our synthesized complex has Molecular weight less than 450, so it may be highly absorbed because most of the traded drugs, i.e. approximately $80 \%$ has Molecular weights in this range. The complex with molecular weight 595.79 also shows drug likeness as $20 \%$ traded drug has molecular weight more than 450 . The $\log \mathrm{P}$ value of the synthesized complexes fall in the standard range, i.e., less than 5 so these compounds may be highly hydrophilic and thus meet the criteria of market drugs.

Table 5. Molinspiration calculations of the complexes 1-4 and standard drugs.

\begin{tabular}{|l|l|l|l|l|l|l|}
\hline Data & $\mathbf{1}$ & $\mathbf{2}$ & $\mathbf{3}$ & $\mathbf{4}$ & Azithromycin & Terbinafine \\
\hline LogP & 1.98 & -1.59 & -1.59 & -1.59 & 2.73 & 5.72 \\
\hline TPSA & 220.92 & 116.45 & 116.45 & 116.45 & 180.09 & 3.24 \\
\hline Natoms & 39 & 18 & 18 & 18 & 52 & 22 \\
\hline MW & 595.79 & 253.19 & 253.19 & 253.19 & 749.00 & 291.44 \\
\hline nON & 16 & 8 & 8 & 8 & 14 & 1 \\
\hline nOHNH & 2 & 1 & 1 & 1 & 5 & 0 \\
\hline Nviolations & 2 & 0 & 0 & 0 & 2 & 1 \\
\hline Nrotb & 14 & 6 & 6 & 6 & 7 & 4 \\
\hline volume & 460.31 & 205.99 & 205.99 & 205.99 & 736.45 & 306.73 \\
\hline GPCR ligand & -0.18 & -0.39 & -0.39 & -0.39 & -0.60 & 0.29 \\
\hline ICM & -0.36 & -0.29 & -0.29 & -0.29 & -1.50 & 0.37 \\
\hline KI & -0.20 & -0.44 & -0.44 & -0.44 & -1.35 & 0.10 \\
\hline NRL & -0.22 & -0.54 & -0.54 & -0.54 & -1.40 & 0.44 \\
\hline PI & -0.17 & -0.47 & -0.47 & -0.47 & -0.28 & 0.19 \\
\hline EI & -0.16 & -0.17 & -0.17 & -0.17 & -0.82 & 0.68 \\
\hline
\end{tabular}

ICM: Ion channel modulator; KI: Kinase inhibitor; NRL: Nuclear receptor ligand; PI: Protease Inhibitor; EI: Enzyme Inhibitor.

\section{Osirisis calculations}

The Osiris calculations are given in Table 6. Toxicity risks and physic-chemical properties of complexes were evaluated and analyzed by the methodology developed by Osiris. It is necessary for a good drug to have high hydrophilicity and $\operatorname{low}$ cLogP value (cLogP value must not be 
greater than 5.0). It may lead to poor absorption and permeation if a drug lacks such contents. Compounds having $c \operatorname{LogP}>5$ have a good absorption ability. Upon such recommendations all the complexes exhibit $c \log \mathrm{P}$ values in the satisfactory range. Here ' $\mathrm{S}$ ' shows the aqueous solubility capability of a compound. The screened compounds may be recommended to be introduce as an innovative drug because they have the ' $S$ ' value range (Table 7) which meets about $80 \%$ of Drug market criterion (S value greater than -4 ). The toxicity effects of the synthesized complex were also determined through Osiris analysis which helps in determining risky fragment. All the synthesized complexes have less toxicity risk as a whole and fulfill the requirements of the drug market up to some extent.

Table 6. Toxicity assessment of synthesized compounds.

\begin{tabular}{|c|c|c|c|c|}
\hline \multirow{2}{*}{ Compounds } & \multicolumn{4}{|c|}{ Toxicity Risks } \\
\cline { 2 - 5 } & Mutagenic & Tumorigenic & Irritant & Reproductive Effect \\
\hline HL & not toxic & not toxic & not toxic & not toxic \\
\hline NaL & not toxic & not toxic & not toxic & not toxic \\
\hline 1 & Toxic & not toxic & not toxic & not toxic \\
\hline 2 & Toxic & not toxic & not toxic & not toxic \\
\hline 3 & Toxic & not toxic & not toxic & not toxic \\
\hline 4 & Toxic & not toxic & not toxic & not toxic \\
\hline
\end{tabular}

Table 7. Bio-availability and DS* of the synthesized compounds.

\begin{tabular}{|c|c|c|c|c|c|}
\hline \multirow{2}{*}{ Compounds } & \multicolumn{5}{|c|}{ Bio-availability and DS } \\
\cline { 2 - 6 } & cLogP & S & TPSA & Drug likeness & DS \\
\hline HL & -0.25 & -2.22 & 121.4 & -4.28 & 0.48 \\
\hline $\mathrm{NaL}$ & -0.4 & -2.21 & 119.4 & -4.24 & 0.43 \\
\hline 1 & -1.28 & -2.11 & 115.4 & -5.4 & 0.26 \\
\hline 2 & -1.268 & -2.11 & 115.4 & -5.4 & 0.26 \\
\hline 3 & -1.28 & -2.11 & 115.4 & -5.4 & 0.26 \\
\hline 4 & -1.28 & -2.11 & 115.4 & -5.4 & 0.26 \\
\hline
\end{tabular}

*DS: Drug score; S: solubility.

\section{Molecular docking studies}

Molecular docking studies were carried out in order to find out the binding mode of the metal complexes and to information about the proper orientation of DNA bounded complex yielding a stable adduct. It was also confirmed by Molecular docking studies that the binding mode of complex to DNA is intercalative. In intercalation due to the introduction of an intercalator into DNA base pairs the DNA double helix arrangements may be stabilize, stiffen, lengthen and unwind. The Zn carboxylate complex analogs were docked with DNA and the results showed that the most potent inhibitor was complex 4. It was observed that this complex made one Hacceptor and two pi-H interactions with DC3 and DG4 residues of DNA respectively as shown in Figure 2B.

\section{CONCLUSION}

All the complexes were synthesized in good yield. The expected composition was confirmed by EDX analysis. It was shown that the complex interact with DNA through intercalative binding mode which was checked using UV-Visible Spectroscopy. The intercalative mode of binding was also confirmed through viscometry and Molecular docking studies. The result of the Molecular docking study revealed that complex interacts with one $\mathrm{H}$-acceptor and two pi-Hs with DC3 and DG4 residues of DNA, respectively. The results of DNA damage activity show 
that the synthesized complexes compared to $\mathrm{H}_{2} \mathrm{O}_{2}$ (control) have no obvious DNA laddering profile. Further the lower DNA damage activity of these complexes enhances their importance in drug development field. The hemolytic activity results exhibited that the screened complexes showed concentration dependent hemolysis. The POM analysis were also carried out which demonstrated that the synthesized complexes might be an innovative addition in drug development. The lack of DNA degradation ability and cytotoxicity to human blood erythrocytes increment the significance of these complexes in the field of drug development.

\section{ACKNOWLEDGMENTS}

The authors Muhammad Sirajud Din and Hizbullah Khan are thankful to Higher Education Commission Pakistan for financial support under grant No.10669/KPK/NRPU/R\&D/HEC/ 2017.

\section{REFERENCES}

1. Ali, H.A.; Omar, S.N.; Darawsheh, M.D.; Fares, H. Synthesis, characterization and antimicrobial activity of zinc(II) ibuprofen complexes with nitrogen-based ligands. J. Coord. Chem. 2016, 69, 1110-1122.

2. Dos Santos, P.R.; Pich, C.T.; Back, D.; Smiderle, F.; Dumas,F.; Moura, S. Synthesis, chemical characterization and DNA interaction study of new diclofenac and ibuprofen zinc (II)-nicotinamide ternary complexes as cyclooxygenase inhibitor prototypes. J. Inorg. Biochem. 2020, 206, 111046.

3. Darawsheh, M.; Ali, H.A.; Abuhijleh, A.L.; Rappocciolo, E.; Akkawi, M.; Jaber, S.; Maloul, S.; Hussein, Y. New mixed ligand zinc(II) complexes based on the antiepileptic drug sodium valproate and bioactive nitrogen-donor ligands. Synthesis, structure and biological properties. Eur. J. Med. Chem. 2014, 82, 152-163.

4. Sirajuddin, M.; Ali, S.; McKee, V.; Wadood, A.; Ghufran, M. Exploration of organotin(IV) derivatives for medicinal applications: Synthesis, spectroscopic characterization, structural elucidation and molecular docking study. J. Mol. Struct. 2019, 1181, 93-108.

5. Ullah, K.; Sirajuddin, M.; Zubair, M.; Haider, A.; S.; Ali, Ullah, F.; Dutkiewicz, G.; Kubicki, M.; Rizzoli, C. Designing of homo and heteroleptic zinc(II) carboxylates: Synthesis, spectroscopic characterizations, DNA binding study, CTAB interaction and in vitro antimicrobial evaluations. J. Iran. Chem. Soc. 2019, 16, 1163-1177.

6. Hu, K.; Jin, S.; Xie, Z.; Guo, M.; Lin, Z.; Wang, D. Construction of nine non-covalentlybonded zinc(II) and cadmium(II) supramolecules containing the mixed-ligands of 3,5dimethylpyrazole and carboxylates: Their synthesis and characterization. Polyhedron 2018, $139,17-32$.

7. Nisa, M.; Sirajuddin, M.; Ali, S.; Tahir M.N.; Iqbal, M. Synthesis, characterization crystal structures and DNA binding studies of zinc complexes with oxygen and nitrogen donor ligands. Polyhedron 2020, 177, 114273.

8. Grabner, S.; Modec, B. Zn(II) curcuminate complexes with 2,2'-bipyridine and carboxylates. Molecules 2019, 24, 2540.

9. Pucci, D.; Crispini, A.; Mendiguchia, B.S.; Pirillo, S.; Ghedini, M.; Morelli S.; Bartolo, L.D. Improving the bioactivity of $\mathrm{Zn}(\mathrm{II})$-curcumin based complexes. Dalton Trans. 2013, 42, 9679-9687.

10. Chukwuma, C.I.; Mashele, S.S.; Eze, K.C.; Matowane, G.R.; Islam, S.M.; Bonnet, S.L.; Noreljaleel, A.E.M.; Ramorobi, L.M. A comprehensive review on zinc(II) complexes as anti-diabetic agents: The advances, scientific gaps and prospects. Pharmacol. Res. 2020, $155,104744$. 
11. Saswati; Mohanty, M.; Banerjee, A.; Biswal, S.; Horn, Jr., A.; Schenk, G.; Brzezinski, K.; Sinn, E.; Reuter, H.; Dinda, R. Polynuclear zinc(II) complexes of thiosemicarbazone: Synthesis, X-ray structure and biological evaluation. J. Inorg. Biochem. 2020, 203, 110908.

12. Zafar, R.; Zubair, M.; Ali, S.; Shahid, K.; Waseem, W.; Naureen, H.; Haider, A.; Jan, M.S.; Ullah, F.; Sirajuddin M.; Sadiq, A. Zinc metal carboxylates as potential anti-Alzheimer's candidate: In vitro anticholinesterase, antioxidant and molecular docking studies. J. Biomol. Struct. Dyn. 2021, 39, 1044-1054.

13. Sun, M.; Hou, Y.; Wang, X.; Li, T.T.; Cao, W.; Zhang, X. Synthesis and crystal structure of two new $\mathrm{Zn}(\mathrm{II})$ and $\mathrm{Ni}(\mathrm{II})$ coordination polymers with anti-ovarian cancer activity. Inorg. Nano-Met. Chem. 2021, 51, 182-187.

14. Dutta, N.; Majumder, A.; Das, A.; Chatterjee, A.; Tarafder, M.; Datta, B.; Bera, M. Synthetic, structural, spectral and DNA binding aspects of copper(II), nickel(II) and zinc(II) dimers of new carboxylate-based tripodal ligand. J. Mol. Struct. 2020, 1206, 127708.

15. Iqbal, M.; Karim, A.; Ali, S.; Bilal H.; Rehman, A.U. Synthesis, characterization, structural description, micellization behavior, DNA binding study and antioxidant activity of 4, 5 and 6-coordinated copper(II) and zinc(II) complexes. Z. Anorg. Allg. Chem. 2020, 646, 895-903.

16. Uddin, N.; Sirajuddin, M.; Uddin, N.; Tariq, M.; Ullah, H.; Ali, S.; Tirmizi, S.A.; Khan, A.R. Synthesis, spectroscopic characterization, biological screenings, DNA binding study and POM analyses of transition metal carboxylates. Spectrochim. Acta A, Mol. Biomol. Spectrosc. 2015, 140, 563-574.

17. Sirajuddin, M.; Ali, S.; McKee, V.; Akhtar, N.; Andleeb, S.; Wadood, A. Spectroscopic characterizations, structural peculiarities, molecular docking study and evaluation of biological potential of newly designed organotin(IV) carboxylates. J. Photochem. Photobiol. B 2019, 197, 111516.

18. Zubair, M.; Sirajuddin, M.; Haider, A.; Ullah, K.; Ullah, I.; Munir, A.; Ali, S.; Tahir, M.N. Synthesis, physicochemical characterizations and in vitro biological evaluations of amide based Zn(II) carboxylates. Inorgan. Chimi. Acta 2018, 482, 567-578.

19. Sirajuddin, M.; Ali, S.; Shahnawaz, A.; Perveen, F.; Andleeb, S.; Ali, S. Exploration of biological potency of carboxylic acid derivatives: Designing, synthesis, characterizations and molecular docking study. J. Mol. Struct. 2020, 1207, 127809.

20. Tahir, M.; Sirajuddin, M.; Haider, A.; Ali, S.; Nadhman, A.; Rizzoli, C. Synthesis, spectroscopic characterization, crystal structure, interaction with DNA, CTAB as well as evaluation of biological potency, docking and molecular dynamics studies of N-(3,4,5trimethoxybenzylidene)-2,3-dimethylbenzenamine. J. Mol. Struct. 2019, 1178, 29-38.

21. Zubair, M.; Sirajuddin, M.; Ullah, K.; Haider, A.; Perveen, F., Hussain, I.; Ali, S.; Tahir, M.N. Synthesis, structural peculiarities, theoretical study and biological evaluation of newly designed o-Vanillin based azomethines. J. Mol. Struct. 2020, 1205, 127574.

22. Aziz, I.; Sirajuddin, M.; Munir, A.; Tirmizi, S.; Nadeem, S.; Tahir M.N.; Sajjad, W. Synthesis, characterization, DNA interaction study, antibacterial and anticancer activities of new palladium(II) phosphine complexes. Russ. J. Gen. Chem. 2018, 88, 551-559.

23. Noureen, S.; Sirajuddin, M.; Ali, S.; ShaheenF.; Tahir, M.N. Synthesis, structural elucidation and DNA binding study of fluorine substituted organotin(IV) dithiocarbamates. Polyhedron 2015, 102, 750-758.

24. Munir, A.; Sirajuddin, M.; Zubair, M.; Haider, A.; Tirmizi, S.A.; Ali, S.; Khan, H.; Ullah, K.; Aziz, I. Synthesis, spectroscopic characterization, and biological screening of levofloxacin based organotin(IV) derivatives. Russ. J. Gen. Chem. 2017, 87, 2380-2390.

25. Sevgi, F.; Bagkesici, U.; Kursunlu, A.N.; Guler, E. Fe(III), Co(II), Ni(II), Cu(II) and Zn(II) complexes of Schiff bases based-on glycine and phenylalanine: Synthesis, magnetic/thermal properties and antimicrobial activity. J. Mol. Struct. 2018, 1154, 256-260. 
26. Kumar, K.; Murugesan, S. Synthesis, characterization and anti-bacterial activity of divalent transition metal complexes of hydrazine and trimesic acid. J. Saudi Chem. Soc. 2018, 22, 1626.

27. Vimalraj, S.; Rajalakshmi, S.; Saravanan, S.; Preeth, D.R.; Vasanthi, R.L.; Shairam, M.; Chatterjee, S. Synthesis and characterization of zinc-silibinin complexes: A potential bioactive compound with angiogenic, and antibacterial activity for bone tissue engineering. Colloids Surf. B Biointerfaces 2018, 167, 134-143.

28. Abbas, S.M.; Sirajuddin, M.; Ali, S.; Hussain, S.T.; Shah F.A.; Meetsma, A. Synthesis, characterization, X-ray structure and biological screenings of silver(I) and copper(I) complexes of triphenylphosphinedithiocarboxylate. J. Chem. Soc. Pak. 2013, 34, 859-867.

29. Abbas, S.M.; Sirajuddin, M.; Shah, F.A.; Ali S.; Ahmad, S. Synthesis, characterization and antimicrobial activity of potential bioactive organotin(IV) dithiocarboxylates. J. Chem. Soc. Pak. 2013, 35, 1399-1407.

30. Aziz, I.; Sirajuddin, M.; Nadeem, S.; Tirmizi, S.A.; Imad, R.; Sajjad, W. Synthesis, spectral characterization and evaluation of biological properties of $\mathrm{Pd}(\mathrm{II})$ tris-4-cholorophenyl phosphine complexes of thioureas and heterocyclic thiones. J. Chem. Soc. Pak. 2018, 40, 171-181

31. Balouiri, M.; Sadiki, M.; Ibnsouda, S.K. Methods for in vitro evaluating antimicrobial activity: A review. J. Pharm. Biomed. Anal. 2016, 6, 71-79.

32. Khanam, S.; Shahid, K.; Sirajuddin, M.; Ali, S.; Ullah, H. Synthesis, spectral characterization and biological evaluation of organotin(IV) complexes of aniline derivatives of naturally occurring betulinic acid. J. Chem. Soc. Pak. 2019, 41, 725-734.

33. Tighadouni, S.; Radi, S.; Sirajuddin, M.; Akkurt, M.; Özdemir, N.; Ahmad, M.; Mabkhot, Y.N.; Hadda, T.B. In vitro antifungal, anticancer activities and pom analyses of a novel bioactive Schiff base 4-\{[(E)-furan-2-ylmethylidene $]$ amino $\} \quad p$-henol: Synthesis, characterization and crystal structure. J. Chem. Soc. Pak. 2016, 38, 157-165.

34. Mehwish, S.; Khan, H.; Rehman, A.U.; Khan, A.U.; Khan, M.A.; Hayat, O.; Ahmad, M.; Wadood, A.; Ullah, N. Natural compounds from plants controlling leishmanial growth via DNA damage and inhibiting trypanothione reductase and trypanothionesynthetase: An in vitro and in silico approach. Biotech. 2019, 9, 1-14.

35. Silveira, F.T.; Lainson, R.; Corbett, C.E. Clinical and immunopathological spectrum of American cutaneous leishmaniasis with special reference to the disease in Amazonian Brazil: A review. Mem. Inst. Oswaldo Cruz. 2004, 99, 239-251.

36. Nadhman, A.; Nazir, S.; Khan, M.I.; Arooj, S.; Bakhtiar, M.; Shahnaz, G.; Yasinzai, M. PEGylated silver doped zinc oxide nanoparticles as novel photosensitizers for photodynamic therapy against Leishmania. Free Radic. Biol. Med. 2014, 77, 230-238.

37. Su, W.Y.; Pan, R.K.; Song, J.L.; Li, G.B.; Liu, S.G. Synthesis, crystal structures and cytotoxic activity of two zinc(II) complexes derived from benzimidazole derivatives. Polyhedron 2019, 161, 268-275.

38. Tomimatsu, N.; Mukherjee, B.; Burma, S. Distinct roles of ATR and DNA-PKcs in triggering DNA damage responses in ATM-deficient cells. EMBO Rep. 2009, 10, 629-635.

39. Neelakantan, M.; Balakrishnan, C.; Balamurugan, K.; Mariappan, S. Zinc(II)- $\mathrm{N}_{2} \mathrm{O}_{2}$ ligation complex-based DNA/protein binder and cleaver having enhanced cytotoxic and phosphatase activity. Appl. Organomet. Chem. 2018, 32, e4400.

40. Gao, E.J.; Feng, Y.H.; Su, J.Q.; Meng, B.; Jia, B.; Qi, Z.Z.; Peng, T.T.; Zhu, M.C. Synthesis, characterization, DNA binding, apoptosis and molecular docking of three $\mathrm{Mn}(\mathrm{II}), \mathrm{Zn}(\mathrm{II})$ and $\mathrm{Cu}(\mathrm{II})$ complexes with terpyridine-based carboxylic acid. Appl. Organomet. Chem. 2018, 32, e4164.

41. Ikeda, N.E.A.; Novak, E.M.; Maria, D.A.; Velosa, A.S.; Pereira, R.M.S. Synthesis, characterization and biological evaluation of rutin-zinc(II) flavonoid-metal complex. Chem. Biol. Interact. 2015, 239, 184-191. 
42. Leach, A.R.; Shoichet, B.K.; Peishoff, C.E. Prediction of protein-ligand interactions. Docking and scoring: Successes and gaps. J. Med. Chem. 2006, 49, 5851-5855.

43. ULC, C. Molecular Operating Environment (MOE), 1010 Sherbooke St, West, Suite, 2017, 910.

44. Sirajuddin, M.; Ali, S.; McKee, V.; Zaib, S.; Iqbal, J. Organotin(IV) carboxylate derivatives as a new addition to anticancer and antileishmanial agents: Design, physicochemical characterization and interaction with Salmon sperm DNA. RSC Adv. 2014, 4, 57505.

45. Papageorgiou, S.K.; Kouvelos, E.P.; Favvas, E.P.; Sapalidis, A.A.; Romanos, G.E.; Katsaros, F.K. Metal-carboxylate interactions in metal-alginate complexes studied with FTIR spectroscopy. Carbohydr. Res. 2010, 345, 469-473.

46. Sirajuddin, M.; Ali, S.; Shah, N.A.; Khan, M.R.; Tahir, M.N. Synthesis, characterization, biological screenings and interaction with calf thymus DNA of a novel azomethine 3-((3,5dimethylphenylimino) methyl) benzene-1,2-diol. Spectrochim. Acta A 2012, 94, 134-142.

47. Sirajuddin, M.; Ali, S.; McKee, V. Synthesis, spectroscopic characterization and in vitro antimicrobial, anticancer and antileishmanial activities as well interaction with Salmon sperm DNA of newly synthesized carboxylic acid derivative, 4-(4-methoxy-2nitrophenylamino)-4-oxobutanoic acid. Spectrochim. Acta A 2015, 138, 569-578.

48. Sirajuddin, M.; Ali, S.; Shah, F.A.; Ahmad M.; Tahir, M.N. Potential bioactive vanillinSchiff base di-and tri-organotin(IV) complexes of 4-((3,5-dimethylphenylimino) methyl)-2methoxyphenol: Synthesis, characterization and biological screenings. J. Iran. Chem. Soc. 2014, 11, 297-313.

49. Ribeiro, T.G.; Nascimento, A.M.; Henriques, B.O.; Chávez-Fumagalli, M.A.; Franca, J.R.; Duarte, M.C.; Lage, P.S.; Andrade, P.H.; Lage, D.P.; Rodrigues, L.B. Antileishmanial activity of standardized fractions of Stryphnodendron obovatum (Barbatimao) extract and constituent compounds. J. Ethnopharmacol. 2015, 165, 238-242.

50. De Bot, S.T; Willemsen, M.A.A.P; Vermeer, S.; Kremer, H.P.H.; B.P.; van de Warrenburg, B.P.C. Reviewing the genetic causes of spastic-ataxias. Neurology 2012, 79, 1507-1514. 